уделяется внедрению инклюзивного образования в Украине с учетом Общеевропейских рекомендаций языкового образования, что привело к поиску новых путей и методов обучения иностранному языку детей с психофизическими расстройствами.

Определяются причины, обусловливающие необходимость исследования способов и методов преподавания английского языка как иностранного детям с РАС, что обеспечит их адаптацию в инклюзивном классе и социализацию в обществе. В Советской Украине детей с ограниченными возможностями обучали в специализированных школах, но сегодня в Канаде, США и европейских странах есть впечатляющий опыт привлечения детей с особыми образовательными потребностями к обучению в ближайших государственных школах. Поскольку этот подход получает широкое распространение в Украине, актуальным является поиск путей обеспечения надлежащего уровня образования всех детей без исключения.

Человек с аутизмом, как правило, испытывает трудности в общении, в овладении языком, социальными и когнитивными навыками, поэтому дети с аутизмом лучше учатся при помощи наглядности, имитации и в упорядоченной среде для обучения, учитывающей их сенсорную чувствительность. Кроме того, им приходится бороться с последствиями негативного отношения к людям с инвалидностью в целом. Родители и профессионалы сходятся во мнении, что каждый ребенок с расстройством аутистического спектра является уникальным, нужно много усердной работы, чтобы помочь ребенку с аутизмом, ведь каждый имеет различные потребности и поддается определенному стилю обучения.

Взаимодействие с другими детьми при помощи игр поможет получить опыт вне класса. Упорядоченная среда способствует развитию у ребенка чувства защищенности и открытости к обучению. Основной формой интерактивной работы является учебное взаимодействие учащихся в парах и микрогруппах. Группы изучают учебный материал и формируют межличностные навыки.

Эффективность этих упражнений зависит от того, насколько выполняются следующие условия: системность; их распределение в порядке увеличения сложности; чередование и разнообразие упражнений.

Ключевые слова: аутизм, особые образовательные потребности, психологическая адаптация, способы обучения, инклюзия.

DOI: https://doi.org/10.32782/2410-0927-2020-13-22

УДК $811.111(73)^{\prime} 42-11$

Олена Світліковська

\title{
ВЕРБАЛІЗАТОРИ КОНЦЕПТУ «VALUЕS» В АМЕРИКАНСЬКІЙ ЛІНГВОКУЛЬТУРІ (НА МАТЕРІАЛІ МАСМЕДІЙНИХ ТЕКСТІВ)
}

У статті досліджено американську лінгвокультурну систему цінностей через концепт ЦІНHОCTI / VALUES. Ключові цінності поділяємо на такі основні групи: вітальні цінності, соціальні, політичні, моральні, релігійні й ідеологічні, художньо-естетичні, родинні, трудові. Створено номінативне поле концепту VALUES на основі мовних засобів, які його репрезентують. Структура номінативного поля концепту представлена у вигляді ядра та периферії, до яких входить значення певної лексеми, представлене гіперсемою/гіперсемами - семантичним компонентом вищого порядку, що організовує навколо себе розгортання семантичного поля. Для встановлення ядра номінативного поля концепту VALUES в американському масмедійному дискурсі були опрацьовані дефініції ключової лексеми, а також пов'язаних із нею лексем у словниках та тезаурусах. Шляхом аналізу лексикографічних джерел установлено синонімічне розширення ключової лексеми та одиниць, пов'язаних з нею. Виокремлено низку соціокультурних цінностей американського суспільства, зокрема personal control over the environment; change; time and its control; equality / egalitarianism;individualism; privacy; individual achievement (status, success); self-reliance / independence; competition; future orientation; action / work orientation; informality; directness / openness / honesty; patriotism тощо. Здійснено аналіз частотності вживання ключових лексем та їх синонімічних розширень. Установлено, що до ядра концепту VALUES належить складник Action / Work orientation. До навколоядерної зони входять: Equality / Egalitarianism, Time and its control, Change, Individual achievement (status, success), Materialism / Acquisitiveness (possess(iveness), consume(rs), customer(s), goods, services), Privacy, Value(s) тощо. Складовими периферії концепту VALUES є: Practicality, Individualism, Competition, Personal control over the environment, Future orientation, Directness / openness / honesty (sincerity, sobriety, straightforward, frankness, earnest, etc.), American liberalism and capitalism, Informality тощо.

Ключові слова: система цінностей, номінативне поле, вербалізатори концепту, ядерна зона, навколоядерна зона, периферійна зона.

(C) Світліковська О., 2020 
Вступ. Питання цінностей є актуальним та міждисциплінарним. На думку науковців, котрі працюють у сфері культурології, лінгвокультурології чи соціолінгвістики, цінності становлять серцевину культури, оскільки вони відображають колективне уявлення про те, що $\epsilon$ бажаним чи небажаним у певній культурі [14, с. 46]. Міждисциплінарний підхід до аналізу цінностей грунтується на ментальних, етичних, естетичних, психологічних складових частинах, які реалізуються в мовленні вербально та невербально, розглядають як прояв культури, індивідуального досвіду людей та соціальних і суспільних процесів.

Лінгвокультурологічне дослідження аналізу мовних картин світу загалом та систем цінностей зокрема проведено в працях як вітчизняних, так і зарубіжних учених, серед яких -
І. О. Голубовська,
С. А. Жаботинська,
B. В. Красних,
О. С. Кубрякова,
В. А. Маслова,

O. О. Селіванова, Ю. С. Степанов, В. М. Телія, W. Bilsky, R. Gakendoff, R. M. Keesing, G. Lakoff та ін.

Актуальність нашого дослідження зумовлена потребою сучасної лінгвістики до конкретизації концептів як вербалізованих культурних смислів і цінностей, задля вербалізації яких існує мова.

Мета нашого дослідження - виокремити мовні засоби, які репрезентують концепт $\boldsymbol{V A L U E S}$ в американській лінгвокультурі, та описати його номінативне поле. Для досягнення заявленої мети потрібно виконати такі завдання:

- з'ясувати, що таке номінативне поле;

- представити та описати номінативе поле концепту $\boldsymbol{V A L U E S}$;

- проаналізувати лексико-семантичні групи, які становлять ядерну та периферійну зону номінативного поля концепту $\boldsymbol{V A L U E S .}$

Для виконання завдань i досягнення поставленої мети застосовано такі загальнолінгвістичні методи та методики дослідження, як загальнонауковий гіпотетикодедуктивний, що передбачає добір фактичного мовного матеріалу; метод контекстуального аналізу використано для детального аналізу лінгвальних і позамовних чинників впливу на специфіку вербальної поведінки мовця; елементи кількісного аналізу застосовано для підрахунку вербалізаторів концептів і їхніх когнітивних ознак; метод дискурсивного аналізу застосовували для аналізу лексичних значень одиниць, що вживаються в дискурсі; метод контент-аналізу - для виокремлення вербалізаторів концептів.

Результати та дискусії. У системі загальнолюдських цінностей виокремлюють такі основні групи: вітальні цінності, соціальні, політичні, моральні, релігійні й ідеологічні, художньо-естетичні, родинні, трудові [4, с. 138]. Усі ці групи мають певні особливості для кожної конкретної нації. Систему цінностей можна представити як концепт ЦІННОСТІ/ $\boldsymbol{V A L U E S , ~ о с к і л ь к и ~ к о н ц е п т ~ я к ~ м е н т а л ь н е ~ у т в о р е н н я ~ у ~ с в і д о м о с т і ~ і н д и в і д а ~} є$ виходом на концептосферу соціуму, тобто в кінцевому результаті - на культуру, а концепт як одиниця культури, є фіксацією колективного досвіду, що стає надбанням індивіда [1, с. 35]. Отже,

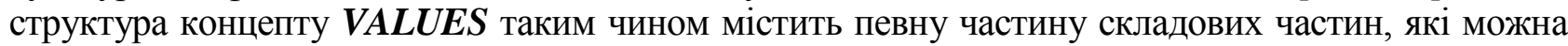
назвати універсальними, та частину компонентів, які є культурно маркованими.

Сукупність мовних засобів, які репрезентують концепт у певний період розвитку суспільства, 3. Д. Попова та Й. А. Стернін називають номінативним полем концепту. Номінативне поле має комплексний характер і не функціонує як структурне угруповання в системі мови, а $є$ виявленою та впорядкованою дослідником сукупністю номінативних одиниць [5, с. 66-68]. Номінативне поле включає одиниці всіх частин мови, воно принципово неоднорідне, оскільки містить як прямі номінації самого концепту безпосередньо (ядро номінативного поля), так і номінації окремих когнітивних ознак концепту, які розкривають зміст концепту та ставлення до нього в різних комунікативних ситуаціях (периферія номінативного поля) [1, с. 38].

Вербалізаторами концептів називають лексеми, за допомогою яких концепти об'єктивуються у мові. Структура номінативного поля концепту може бути представлена в вигляді ядра й периферії. До ядра входить словесне значення певної лексеми, представлене гіперсемою/гіперсемами - семантичним компонентом вищого порядку, що організовує навколо себе розгортання семантичного поля. Центр поля складається з одиниць, що мають інтегральне, спільне $з$ ядром диференційне значення. Периферія включає найбільш віддалені від ядра 
одиниці, спільне родове значення яких належить до потенційної, імовірнісної семантики [6, с. 8]. За частотністю використання певних ознак виділяють ближню й віддалену периферію.

Для встановлення ядра номінативного поля концепту $\boldsymbol{V A L U E S}$ в американських масмедійних текстах опрацьовано визначення та тлумачення ключової лексеми, а також лексем, які пов'язані з нею, у словниках та тезаурусах $[1 ; 2 ; 3 ; 4 ; 5 ; 6 ; 7 ; 8 ; 9 ; 10 ; 11 ; 12 ; 13]$.

Аналіз словникових дефініцій дав змогу встановити, що тлумаченнями ключової лексеми value(s), які виступають релевантними для нашого дослідження, $\epsilon$ такі: a strongly held belief about what is valuable, important or acceptable - usually plural; something (such as a principle or quality) intrinsically valuable or desirable; a quality that gives something special worth $[1 ; 2 ; 3 ; 4 ; 5$; $6 ; 7 ; 8 ; 9 ; 10 ; 11 ; 12 ; 13]$.

За допомогою аналізу лексикографічних джерел установлено синонімічне розширення ключової лексеми та одиниць, пов'язаних з нею. Ми виокремили такі лексеми, як cardinal virtues, distinctions, excellences, excellencies, graces, merits, virtues, advantage, edge, plus, superiority. Усi наведені одиниці разом із ключовою лексемою value(s) можемо віднести до ядра концепту VALUES в американському дискурсі, якщо це буде підтверджено частотністю вживання.

Найчастотнішими колокаціями, які запропоновано в словниках, є cultural/moral/ religious values, traditional/conservative/liberal values, values of freedom/justice etc.

Слідом за Р. Колсом ми виокремлюємо соціокультурні цінності, якими живе американське суспільство, а саме: personal control over the environment; change; time and its control; equality/egalitarianism; individualism; privacy; individual achievement (status, success); self-reliance/independence; competition; future orientation; action/work orientation; informality; directness/openness/honesty; patriotism; practicality; efficiency; materialism/acquisitiveness; risk taking; American liberalism and capitalism [8; 17].

Ранжування вищенаведених цінностей в американській лінгвокультурі можна здійснити на основі аналізу частотності вживання відповідних лексем та їх синонімічного розширення в

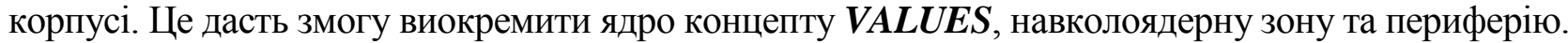

Ми здійснили аналіз частотності вживання ключових лексем, якими репрезентовано вказані цінності, разом із ключовою лексемою value(s), що репрезентує концепт VALUES, та їх синонімічних розширень, які називаємо вербалізаторами концепту VALUES, у The Open American National Corpus (Second Addition) [7]. Виокремлено близько 250 тис. слововживань. Цінності ранжовані відповідно до частотності - від найбільш до найменш частотних у відсотках від загальної кількості слововживань. Отже, можемо побудувати ядро концепту, навколоядерну зону та периферію. Отримані результати представлено у таблиці (див. табл. 1.1).

Таблиия 1.1

Вербалізатори концепту VALUES у американській лінгвокультурі

\begin{tabular}{|l|l|}
\hline Action / Work orientation & $22,6 \%$ \\
\hline Equality / Egalitarianism & $8,5 \%$ \\
\hline Time and its control & $8,5 \%$ \\
\hline Change & $8,3 \%$ \\
\hline Individual achievement (status, success) & $8,2 \%$ \\
\hline Materialism / Acquisitiveness & $6,2 \%$ \\
\hline Privacy & $4,9 \%$ \\
\hline Value (s) & $4,5 \%$ \\
\hline Self-reliance / Independence & $4,5 \%$ \\
\hline Efficiency & $3,9 \%$ \\
\hline Risk taking & $3,8 \%$ \\
\hline Patriotism & $3,1 \%$ \\
\hline Practicality & $2,7 \%$ \\
\hline Individualism & $2,5 \%$ \\
\hline Competition & $2,5 \%$ \\
\hline
\end{tabular}




\begin{tabular}{|l|l|}
\hline Personal control over the environment & $1,5 \%$ \\
\hline Future orientation & $1,2 \%$ \\
\hline Directness / openness / honesty & $1,2 \%$ \\
\hline American liberalism and capitalism & $0,8 \%$ \\
\hline Informality & $0,6 \%$ \\
\hline
\end{tabular}

Отже, отримані результати дають змогу зробити певні висновки щодо структури

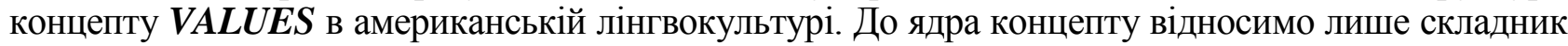
Action / Work orientation, який має частотність уживання 22,6\% від загальної кількості, решта одиниць відзначаються нижчим відсотком, тому, на нашу думку, їх не варто відносити до ядра.

Навколоядерна зона включає компоненти Equality / Egalitarianism (8,5 \%), Time and its control (8,5\%), Change (8,3\%), Individual achievement (status, success) (8,2\%), Materialism / Acquisitiveness (6,2\%), Privacy (4,9\%), Value (s) (4,5\%), Self-reliance / Independence (4,5\%), Efficiency (3,9\%), Risk taking (3,8\%), Patriotism (3,1\%).

Решта виокремлених одиниць становлять периферію структури концепту VALUES. Сюди належать такі складники, як Practicality (2,7 \%), Individualism (2,5\%), Competition (2,5 \%), Personal control over the environment (1,5\%), Future orientation (1,2\%), Directness / openness / honesty (1,2\%), American liberalism and capitalism (0,8 \%), Informality (0,6\%).

Ядро концепту VALUES становить одиниця Action / Work orientation, частотність $22,6 \%$ від загальної кількості, виражена ключовими лексемами work та action 3 усіма словоформами і їх синонімічними розширеннями (у всіх словоформах): affair, labour, employ, output, produce, goods, merchandise, wares, business, job, involvement, participation, calling, occupation, vocation, service, profession, activity тощо. Найчастотнішими лексичними одиницями серед наведених є work (26\%) та business (10\%).

Надзвичайно висока частотність цієї цінності - розрив із наступною найближчою складовою частиною концепту становить понад $14 \%$ - пояснюється тим, що, як стверджує К. С. Карпова, бізнес i гонитва за прибутками вже давно стали невід'ємними складниками сучасного американського суспільства. Потрібно зазначити, що для американців просування кар'єрними сходинками, досягнення успіху й високого соціального статусу, передусім, асоціюються 3 конкурентністю, а не зі співпрацею з іншими [2, с. 12]. Лексеми competition, competitiveness, competitor тощо трапляються в американському корпусі втричі частіше, ніж одиниці cooperation та collaboration. Отже, конкурентна боротьба й конкурентоспроможність належать до ключових рис американського національного характеру, що відбивається в їхній системі цінностей. Недарма американське суспільство характеризують як гіперконкурентне [2, с. 12].

Висока частотність лексеми work загалом (близько 15 тис. слововживань) та в складі вислову hard work (близько 5 тис. слововживань) пояснюється тим, що головний принцип виховання американців - це наполеглива праця, завдяки якій можна досягти всіх вершин й отримати всі блага. Громадянин Сполучених Штатів розраховує на власні сили в досягненні поставленої мети та цим пояснюється високий відсоток такої цінності, як Individual achievement (status, success) (8,2 \%), що входить до навколоядерної зони концепту VALUES. Життєвий успіх оцінюється через індивідуальні досягнення, так само, як і визначається соціальний статус.

Вищенаведені фактори й принцип «покладайся лише на себе» зумовлюють також наявність у системі цінностей американського суспільства такої складової частини як Selfreliance / Independence (4,5 \%), яка за частотністю вживання також уключена до навколоядерної зони концепту. Це можна пояснити також певними історичними чинниками. Америка - країна мігрантів, котрі прибули на новий континент у пошуках кращої долі. Їм доводилося боротись і із силами природи, і з суперниками - такими самими новоприбулими авантюристами. Вони не мали на кого розраховувати, крім самих себе, та покладалися лише на власну міцність i витривалість. Тому не дивно, що в системі цінностей американського суспільства окремо виділяють ще й такий компонент як Risk taking (3,8 \%), яка навіть у XXI ст. займає доволі високий щабель і тому входить до навколоядерної зони концепту VALUES.

Висока частотність цінності Materialism / Acquisitiveness (6,2\%), що вербалізується ключовими лексемами, а також їх синонімічним розширенням, серед яких найчастотнішими $\epsilon$ 
possess(iveness), consume(rs), customer(s), goods, services, також зумовлена вищенаведеними факторами. Американці готові важко працювати, щоб отримати матеріальне благополуччя, забезпечити себе й свої сім'ї. Хоча американське суспільство $є$ доволі благополучним та матеріально забезпеченим, ця складова частина посідає важливе місце в їхній системі цінностей. В американській картині світу багатство, матеріальні блага й гроші - це своєрідний культ [2, с. 9].

Цілком закономірно в системі цінностей Сполучених Штатів з'являється така складова частина, як Efficiency (3,9 \%), яка є доволі частотною та може бути включена до навколоядерної зони концепту VALUES. Готовність до наполегливої праці безпосередньо пов'язана 3 ефективністю праці на противагу марному витрачанню зусиль й зокрема часу.

Час для американців є особливо дорогоцінним і важливим, що відображене в такому складнику концепту VALUES як Time and its control (8,5\%), що посідає другий за частотністю щабель у системі цінностей. Оскільки Америка $є$ доволі молодою країною, порівняно 3 державами Старого Світу й не має такої давньої історії, у іiї громадян особливе ставлення до часу. Вони не мають змоги проводити паралелі з подіями давнини, шукати там пояснення чи причини, усі їх досягнення та здобутки доволі нещодавні з погляду історії. Тому американське суспільство не орієнтоване на те, щоб пишатися подвигами чи героїчними вчинками далекого минулого, а радше дивиться в майбутнє, яке вони самі можуть побудувати.

На наступній сходинці - цінність Change (8,3\%), яка безпосередньо пов'язана 3 попередньою - бажанням тримати час під контролем. Заклик до змін часто стає слоганом президентських кампаній, зокрема в дискурсі Барака Обами це було основою його передвиборчої програми. Американці готові до змін, вони не бояться брати відповідальність за реформування чи трансформації в суспільстві. Цілком імовірно, така цінність сформувалась у їхній свідомості як результат осмислення власної історії - Америка створена людьми, які не побоялися кардинально змінити власне життя, покинути свій дім і вирушити в невідомий світ у пошуках нової кращої долі.

До навколоядерної зони ми також віднесли такі компоненти концепту VALUES як Equality / Egalitarianism (8,5 \%), Privacy (4,9\%), Value (s) (4,5\%), Patriotism (3,1\%).

Америка - багатонаціональна країна, вона $є$ прикладом держави, яка визнає правовий статус кількох етнічних спільнот, які мають рівні права. Тому така цінність, як Equality/ Egalitarianism (8,5 \%) займає другу позицію в ієрархії, разом зі складовою частиною Time and its control. Сполучені Штати завжди вважалися країною рівних можливостей для всіх - не лише громадян, а й іммігрантів, якщо вони готові працювати на благо держави. Кожен індивід оцінюється за власними здобутками, незалежно від раси, релігійних поглядів чи етнічної приналежності. Мультикультуралізм є характерною рисою американського суспільства, яке готове приймати нових членів, якщо вони спроможні стати частиною гомогенної нації зі спільною культурою і єдиною мовою. Американські лідери постійно закликають до єдності під спільним прапором в одній країні, де кожен $є$ рівним перед законом і має однакові права, можливості й обов'язки.

У ядрі сучасної ціннісної системи Сполучених Штатів також спостерігаємо наявність такої складової частини як невтручання в особисте життя, що репрезентовано, передусім лексемою privacy, яка $\epsilon$ ключовою для цінності Privacy (4,9\%), що за доволі високою частотністю входить до навколоядерної зони концепту VALUES. Обмеження втручання в приватне життя людини безпосередньо пов'язане зі свободою особистості, що вважається одним з основних досягнень американського суспільства. Особистий простір громадянина Америки $\epsilon$ недоторканим, він суворо обмежений, тому кожен американець охороняє власний простір і не втручається в чужий. Перетин приватної території заборонений і карається законом. Сполучені Штати дають своїм громадянам право захищати приватну власність зі зброєю в руках.

Традиційно високий щабель у системі цінностей посідає Patriotism (3,1%). Патріотизм, передусім, пов'язаний із вірою американців у свою унікальність, яка передбачає особливу місію в глобальному розумінні, обраність американської нації. Любов до країни, відданість репрезентовані найчастотнішими лексемами із синонімічного розширення ключової лексеми patriotism, а caме: devotion, faithfulness, loyalty. У важкі часи чи під час кризи саме ці риси та звертання до патріотизму допомагали гуртувати націю для боротьби з викликами. 
Складова Value(s) (4,5 \%), репрезентована ключовою лексемою концепту, входить до навколоядерної зони з відносно високою частотністю. Це підтверджує думку, висловлену раніше, що американці сприймають усі вищеописані цінності як невід’ємну складову частину їхньої картини світу, їх світосприйняття, проте не називають це цінностями.

Периферія концепту VALUES утворена одиницями Practicality (2,7\%), Individualism (2,5\%), Competition (2,5\%), Personal control over the environment (1,5\%), Future orientation (1,2\%), Directness / openness / honesty (1,2\%), American liberalism and capitalism (0,8\%), Informality $(0,6 \%)$.

Складники Practicality (2,7 \%) та Competition (2,5\%) безпосередньо пов'язані з цінністю Action / Work orientation, яка становить ядро концепту VALUES. Практичність американців - це основна з характерних рис їхнього суспільства. Американське суспільство грунтується на ідеях Джорджа Вашингтона, Бенджаміна Франкліна, Джеймса Медісона, Томаса Джеферсона, Джона Адамса й інших батьків американської нації. Усі вони і в історичному, і в політичному сенсах були прагматиками, чітко уявляли, що й задля чого вони роблять. Філософські ідеї лібералізму були реалізовані дуже практичним і дієвим способом, що й стало основою для виникнення особливого ставлення до життя, специфічного для американців прагматизму. Практичний американський народ уміє користуватися можливостями, які він отримує, і досягати високих результатів. Навіть після Громадянської війни, яка розпочалася через прагматичні чинники, американське суспільство змогло надзвичайно швидкими темпами збудувати найдемократичнішу й найпотужнішу державу у світі, яка відіграє визначальну роль у світовій політиці та геополітичних процесах і сьогодні.

Наявність складової частини Competition (2,5\%) в ієрархії цінностей американського суспільства підтверджує важливість конкурентоспроможності та конкуренції. Ця ознака не включена до складу інших цінностей, зокрема Action / Work orientation чи Individual achievement (status, success), що було б цілком логічним, а виділена окремо. На конкурентоспроможності грунтується особистий успіх кожного, від якого залежить успіх держави загалом. Винятковість американської нації, власне, полягає в тому, що вона може конкурувати будь із ким. Передусім, ідеться про досягнення в інформаційних технологіях, новітніх підходах до освоєння космосу, проривах у сфері медицини тощо. Із цим пов'язані імена видатних особистостей, які досягли успіху, відомі всьому світові і є предметом гордості для кожного американця, наприклад Ілон Маск, Білл Гейтс, Стів Джобс та ін. Імена видатних американців дуже часто стають прецедентними й із часом починають відіграти роль символів нації.

На цих ядерних цінностях - Action / Work orientation, Individual achievement (status, success), Competition - грунтується один із головних історично-культурних концептів американської лінгвоспільноти - AMERICAN DREAM / AMEРИКАНСЬКА МРІЯ, зміст якого полягає в тому, що кожен американець, який $є$ здібним, енергійним, наполегливим та працьовитим, може досягнути успіху та стати багатим.

Рівність, яка експлікована в складнику Equality / Egalitarianism з навколоядерної зони

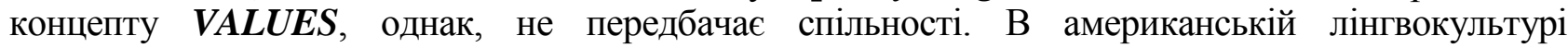
підкреслено важливість окремої особистості - індивіда - над колективною ідентичністю. Саме цим зумовлена наявність цінності Individualism (2,5\%) у периферії концепту VALUES. Важливість індивідуалізму підкреслюється навіть тим, що лексеми individual чи personal присутні у формулюванні основних цінностей американського суспільства - Individual achievement (status, success), Personal control over the environment тощо. У більшості цінностей індивідуалізм якщо не есплікується, то імплікується. Потрібно, проте, зазначити, що американський індивідуалізм має й певний негативний ефект, оскільки він протиставляється родині як загальнолюдській цінності, таким чином ослаблюючи позиції традиційної американської сім'ї через прагнення досягати всього самому та скрізь бути першим [2, с. 7].

Складова Personal control over the environment (1,5\%), що за частотністю включена до периферії концепту VALUES, репрезентована такими лексичними одиницями як environment, environmentalist, climate, climate change, pollution, eco-, похідними від них і т. ін. Масштабна занепокоєність станом навколишнього середовища виникла відносно недавно. Широка громадськість почала звертати серйозну увагу на ступінь руйнування, якого людина завдає 
навколишньому середовищу, десь на початку 60-х років минулого століття. Очевидним для так званих розвинених країн $є$ той факт, що турбота про людство невіддільна від турботи про природу, що доведено наявністю відповідної складової частини в системі цінностей американського суспільства - Personal control over the environment. Вважається, що турбота про навколишне середовище повинна грунтуватися на принципах рівності, права й відповідальності. Оскільки однією з основних характерних рис американців $є$ індивідуалізм, розрахунок лише на себе та власні сили, то й турбота про навколишній світ для них $є$ особистою справою, що підкреслено лексемами Personal control. Для американського суспільства турбота про довкілля $\epsilon$ важливою ще й тому, що, як зазначено в Програмі $\mathrm{OOH}$ із довкілля, погіршення якості навколишнього середовища планети Земля та істотне збільшення ступеня й частоти стихійних лих, таких як циклони, повені та засухи, значною мірою загострюють людську вразливість щодо відсутності продовольчої безпеки, слабкого здоров'я й відсутності стабільних засобів існування [3], а все, що загрожує матеріальному благополуччю, вимагає особливої уваги.

Цінність Future orientation (1,2\%) тісно пов'язана зі складниками Time and its control та Change із навколоядерної зони концепту VALUES. Існування такої цінності в ієрархії вкотре доводить орієнтацію американського суспільства на майбутнє, готовність до змін і прагнення контролювати час.

У периферії концепту $\boldsymbol{V A L U E S}$ виокремлено також такі складові частини, як Directness / openness / honesty (1,2\%) та Informality ( 0,6 \%). Відкритість, прямолінійність і неформальність $\epsilon$ особливими рисами американського національного характеру, які дають змогу відрізнити американців від представників інших націй, зокрема, британців, для яких характерними рисами, як усім відомо, є стриманість та закритість. Складник Directness / openness / honesty (1,2 \%) репрезентований ключовими лексемами й такими лексичними одиницями, як sincerity, sobriety, straightforward, frankness, earnest, etc., серед яких найчастотнішими є frankness, honesty, straightforward. Найчастотнішими лексемами, що репрезентують цінність, $є$ informality, peacefulness та relaxedness.

American liberalism and capitalism $(0,8 \%)$ - це складова частина системи цінностей американського суспільства, що відображає поняття, яке європейці називають «американським лібералізмом». Суть його в тому, що, як вважають громадяни США, чим менше уряду - тим краще $[17$, с. 8$]$. Уряд не повинен утручатися в життя кожного окремого індивіда. Більшість американців не довірять сильному центральному уряду. Саме тому в Америці $є$ й завжди був розподіл влади між трьома гілками - законодавчою, виконавчою та судовою - не в теорії, а на практиці. Особливості вербалізації цієї цінності дають змогу прослідкувати ії тісний зв'язок зі складовими частинами Individualism, Equality / Egalitarianism ma Privacy.

Висновки. Одиниці що репрезентують культурні вияви народу, належать національній мовній свідомості та об'єктивуються в мові елементами, визначеними етнокультурними особливостями тієї картини світу, частиною якої вони є. Зміст концепту VALUES зумовлений специфікою американської лінгвокультури, а засоби його вербалізації віддзеркалюють світогляд та етнокультурні традиції носіїв культури. Модель номінативного поля досліджуваних концептів $\epsilon$ ядерно-периферійною структурою, складники якої мають вербальну реалізацію в американських масмедійних текстах. Значущість когнітивного й лінгвокультурологічного напрямів сучасної концептології є підставою для висновку, що до ядерної та периферійної зон номінтивного поля концепту VALUES входять ключова лексема value(s), пов'язані з нею одиниці, а також їх синонімічне розширення.

До ядра концепту ми відносимо лише складову частину Action / Work orientation, виражена ключовими лексеами: affair, labour, employ, output, produce, goods, merchandise, wares, business, job, involvement, participation, calling, occupation, vocation, service, profession, activity тощо. Результати підрахунку співвідношення кількості одиниць-вербалізаторів концепту $\boldsymbol{V A L U E S}$ у різних сегментах його номінативного поля показали, що в структурі

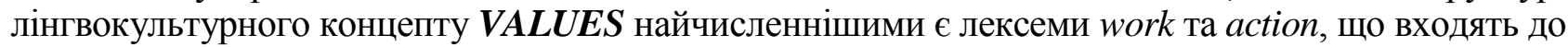
ядра. Навколоядерна зона номінативного поля VALUES уключає компоненти Equality / Egalitarianism, Time and its control, Change, Individual achievement (status, success), Materialism / Acquisitiveness (possess(iveness), consume(rs), customer(s), goods, services), Privacy, Value(s), Self- 
reliance / Independence, Efficiency, Risk taking, Patriotism (devotion, faithfulness, loyalty). Складовими периферії концепту VALUES є: Practicality, Individualism, Competition, Personal control over the environment, Future orientation, Directness / openness / honesty (sincerity, sobriety, straightforward, frankness, earnest, etc.), American liberalism and capitalism, Informality.

Підрахунок лексем-вербалізаторів концептів дав змогу окреслити розподіл концептуальних ознак і їхню концентрацію в певних сегментах номінативних полів.

\section{References}

1. Kalishchuk, Diana. 2018. Kontseptualni styli anglomovnykh politykiv (na materiali politychnogo dyskursu Dzh. Busha mol., B. Obamy). Lutsk: AKVA PRINT.

2. Karpova, Kateryna. 2008. "Verbalizatsiya natsionalno-spetsyfichnykh kontseptiv amerykanskogo suspilstva XX-pochatku XXI stolittia". PhD diss., Kyiv.

3. Kompas: posibnyk z osvity v oblasti prav liudyny za uchasti molodi. URL: http: www.coe.int/uk/web/compass/ environment.

4. Osiptsov, Andriy. 2014. "Sutnist zagalnoliudskykh tsinnostei u filosofsko-sotsiologichnykh doslidzhenniakh". Dukhovnist osobystosti: metodologiia, teoriia i praktyka 1: 130-140.

5. Popova, Zinaida. 2007. Kognitivnaya lingvistika. Moskva: AST: Vostok-Zapad.

6. Frumkina, Revekka. 1998. "Kulturologicheskaya semantika v rakurse epistemologii". Izvestiya RAN. Seriya: Literatura i yazyk 58(1): 3-10.

7. American National Corpus. URL: http://www.anc.org/data/anc-second-release/frequency-data/

8. Kohls, Robert L. 1984. The values Americans live by. URL: https://www.fordham.edu/download/ downloads/id/3193/values_americans_live_by.pdf

9. Longman Handy Learner's Dictionary of American English / ed. by D. Summers. Harlow; Essex: Pearson Education Limited, 2003.

10. Merriam-Webster Learner's Dictionary. URL: https://www.learnersdictionary.com/definition/honour

11. Merriam-Webster Online Thesaurus. URL: www.merriam-webster.com/thesaurus

12. Merriam-Webster's Collegiate Dictionary. $11^{\text {th }}$ ed. Springfield; Massachusetts: Marriam-Webster, Inc., 2004.

13. Roget's 21 st Century Thesaurus. $3^{\text {rd }}$ ed. New York: Random House, Inc., 2005.

14. Schwarz, Monika. 2008. Einführung in die kognitive Linguistik. Tübingen: Francke.

15. The American Heritage Dictionary of the English Language. $4^{\text {th }}$ ed. Boston: The Houghton Mifflin Company, 2000.

16. Weaver Gary R. American cultural values. - URL: https://www.airuniversity.af.edu/Portals/10/AFNC/ documents/Negotiationsectionstef/American\%20Cultural\%20Values.pdf

17. Webster Universal Dictionary / ed. by Wyld H C, Partridge E. H. New York: Harver Educational Services, 1975.

18. Webster's New Thesaurus / ed. by Charlton G. Laird. Cleveland; Ohio: Wiley Publishing, Inc., 2003.

19. Webster's New World Dictionary of American English. $3^{\text {rd }}$ College Edition / ed. by V. Neufeldt. Cleveland; New York: New World Dictionaries, 1989.

20. Webster's New World Thesaurus / prepared L. Charlton. New York: The New American Library, 1975.

21. Webste's Revised Unabridged Dictionary. URL: http://www.lawfulpath. com/ref/webstersUnabridged_1913_ gutenberg.pdf

22. Webster's Third New International Dictionary of the English Language Unabridged / ed. by P. Babcock Gove. Springfield: Marriam-Webster, Inc., 1993.

Свитликовская Елена. Вербализатры концепта «VALUES» в американской лингвокультуре (на материале массмедийных текстов). В статье исследуется американская лингвокультурная систему ценностей через

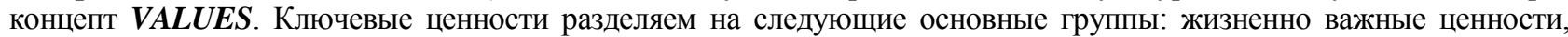
социальные, политические, нравственные, религиозные и идеологические, художественно-эстетические, семейные,

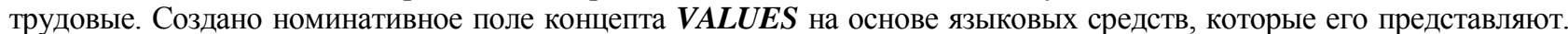
Структура номинативного поля концепта представлена в виде ядра и периферии, в которые входит значение определенной лексемы, представлено гиперсемой / гиперсемами - семантическим компонентом высшего порядка, который организовывает вокруг себя развертывание семантического поля. Для выделения ядра номинативного поля

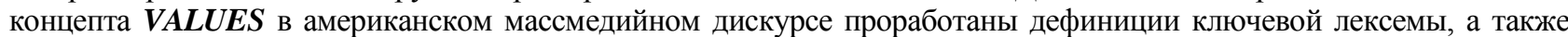
связанных с ней лексем в словарях и тезаурусах. Путем анализа лексикографических источников установлено синонимическое расширение ключевой лексемы и связанных с ней единиц. Выделен ряд социокультурных ценностей американского общества, в частности personal control over the environment; change; time and its control; equality / egalitarianism; individualism; privacy; individual achievement (status, success) self-reliance / independence; competition; future orientation; action / work orientation; informality; directness / openness / honesty; patriotism и т. п. Осуществляется анализ частотности употребления ключевых лексем и их синонимических расширений. Установлено, что к ядру концепта VALUES принадлежит составляющая Action / Work orientation. В околоядерную зону входят: Equality / Egalitarianism, Time and its control, Change, Individual achievement (status, success), Materialism / Acquisitiveness (possess (iveness), consume (rs), customer (s), goods, services), Privacy, Valuе (s) и др. Составляющими периферии концепта VALUES являются Practicality, Individualism, Competition, Personal control 
over the environment, Future orientation, Directness / openness / honesty (sincerity, sobriety, straightforward, frankness, earnest, etc.), American liberalism and capitalism, Informality и т. п.

Ключевые слова: система ценностей, номинативное поле, вербализаторы концепта, ядерная зона, околоядерная зона, периферийная зона.

Svitlikovska Olena. Verbalizers of the Concept «VALUES» in the American Linguoculture (Based on Massmedia Texts). The article investigates the system of values in the American linguoculture through the VALUES concept. We divide the key values into the following main groups: vital, social, political, moral, religious and ideological, artistic and aesthetic, family and labor values. The nominative field of the VALUES concept is created on the basis of linguistic means that reveal it. The structure of the nominative field of the concept is represented by the nuclear and its periphery, which include the meaning of a certain lexeme, introduced by a hyperseme / hypersemes. This higher order semantic component organizes the development of the semantic field around itself. To establish the nuclear of the VALUES concept nominative field in the American media discourse, the definitions of a key lexeme, as well as related lexemes were traced in dictionaries and thesauruses. The analysis of lexicographic sources represented a synonymic expansion of the key lexeme and related units. The following socio-cultural values of the American society were singled out: personal control over the environment; change; time and its control; equality / egalitarianism, individualism; privacy; individual achievement (status, success); self-reliance / independence; competition; future orientation; action / work orientation; informality; directness / openness / honesty; patriotism, etc. The frequency usage analysis of the key lexemes and their synonymic extension is carried out. It is established that the nuclear of the VALUES concept includes Action / Work orientation component. The perinuclear area consists of the following notions: Equality / Egalitarianism, Time and its control, Change, Individual achievement (status, success), Materialism / Acquisitiveness (possess(iveness), consume(rs), customer (s), goods, services), Privacy, Value (s), etc. The peripheral area of the VALUES concept is the following: Practicality, Individualism, Competition, Personal control over the environment, Future orientation, Directness / openness / honesty (sincerity, sobriety, straightforward, frankness, earnest, etc.), American liberalism and capitalism, Informality, etc.

Key words: value system, nominative field, concept verbalizers, nuclear area, perinuclear area, peripheral area.

DOI: https://doi.org/10.32782/2410-0927-2020-13-23

УДК 821.111-34:81’22

Алла Слащук

\section{ЗНАКОВІСТЬ ЯК НЕВІД'СМНИЙ ЕЛЕМЕНТ ЖАНРУ АНГЛІЙСЬКОЇ ЛІТЕРАТУРНОЇ КАЗКИ}

У статті описано результати дослідження стосовно знаковості як невід'ємного елементу жанру англійської літературної казки. Зокрема, висвітлено питання декодування мовного знаку, де знак, репрезентований певною дією чи ситуацією, представляє при цьому інше поняття або явище. Окрім того, проаналізовано семіотичний простір літературної англомовної казки. Установлено, що семіотична система дає змогу об'єднати вигадку, категоріальну ознаку казки, та іï знакову природу. Схарактеризовано значення семіотики у вивченні казкового оповідання. Установлено перспективність дослідження літературної англомовної казки як такої, що стає ще більш художньою, i, як наслідок - більш образною й символічною, де побутові подробиці трапляються поряд із фантастичними явищами. Репрезентовано визначення літературної казки як такої, що має здатність поєднувати реальне та чудесне, зближуючи літературну казку із життям, тим самим створюючи основу для дослідження семантичної ускладненості казкового оповідання й розгляду авторської ідеї на різних рівнях інтерпретації. Проаналізовано важливість трилатеральності знаку, де, окрім єдності плану вираження та плану змісту, третім елементом представлено читача, котрий отримує інформацію шляхом декодування значення знаку, що трапляється в тексті казки. Розглянуто класифікацію знаків Ч. Пірса задля виділення саме тих, що наявні в літературній казці, і можливість їх взаємодії. Отже, виокремлено індексальні знаки, а саме знаки-симптоми та знаки-кінеми, а також подано їх дефініції. Так, симптоми представлено саме умовними знаками для читача, які наділені імпліцитним характером, певними характерними ознаками, що дають додаткову інформацію й наповнюють текст емоційним складником, тоді як знаки-кінеми є конвенційними, свідомими жестами чи мімікою, які несуть «парасемантичне значення». Проілюстровано й доведено індексальність літературної казки, де знаки є можливими засобами передачі не лише умовної поведінки та причинно-наслідкових зв'язків, а й прихованого змісту емоційного стану персонажів.

Ключові слова: семіотика, знаковість, знак, індексальність, кодованість, знак-симптом, знак-кінема, англійська літературна казка.

Вступ. Останнім часом у працях вітчизняних лінгвістів спостерігаємо зацікавленість семіотикою. Учені, аналізуючи мовні засоби, що виконують породження, передачу та збереження інформації про навколишній світ і суспільство, визнають, що успіх комунікації

(C) Слашук А., 2020 